(C) 2016

\title{
Quantitative and qualitative changes of humus at application of organic fertilizer systems in grey forest soil
}

\author{
L. Smishna-Starynska \\ College of state agrarian and engineering university in Podilya
}

The purpose. To determine influence of organic fertilizer systems on quantitative and qualitative changes of humus in 10-field grain-tilling crop rotation in grey wood large-silty sandy loam soil of the Northern part of Forest-steppe of Ukraine. Methods. Field, laboratory, mathematical. Results. Use of soil without fertilization has led to greater losses of humus and aggravation of quality due to mineralization processes predominating above immobilization ones. Amount of fulvic acids was increased and content of humic acids was decreased. Type of formation of humus - fulvate-humate. Under condition of importation of dung in dose of $12 \mathrm{t} / \mathrm{hectare}$ the content of humus was close to reference value, but it was not possible to achieve its positive balance. Amount of humic acids was increased and of fulvic acids was decreased, especially in arable layer of soil. Type of formation of humus in arable layer - humate-fulvate, and in sob-arable - fulvate-humate. At importation of dung in dose of 24 t/hectare the content of humus has reached positive balance with substantial improvement of quality indicators, concerning 12 t/hectare of dung - amount of humic was considerably augmented and the amount of fulvic acids in tillable and sub-arable layers of soil was diminished. Ratio Sga:Sfa in arable layer $-1,90$, in sub-arable $-1,22$. Type of formation of humus humate-fulvate. Conclusions. It is fixed that importation of dung in dose of $12 \mathrm{t} /$ hectare in grain-tilling crop rotation is insufficient for maintenance of sufficient balance of humus, but quality indicators of humus have considerably improved in comparison with the supervisory control. More efficient is the dose of dung of 24 t/hectare, it ensures positive balance of humus and improves its quality contents in tillable and sub-arable layers of soil.

Key words: humus, humic and fulvic acids, type of humus, fractional-group content of humus, optical depth.

The importance of studying the issue of increasing the fertility of different soils in agriculture was and remains in view of the decline in the use of fertilizers, especially organic, due to the decline of the livestock industry. Litter manure - a valuable organic fertilizer. Its chemical composition and fertilizer value are high. With manure, about $75 \%$ of nitrogen is released into the soil in the form of organic compounds and $25 \%$ in the form of ammonium [15]. In fresh poultry, cattle contain more than $20 \%$ of organic matter - these are ready humic compounds (acids), 0,4-0,5\% nitrogen, 0,2 phosphorus, 0,5-0,6\% potassium, trace elements, etc. [1 , 12]. In the last 17 - 20 years in arable land of Ukraine 1 hectare of arable land was introduced from 0.52 to $1 \mathrm{t} /$ ha of manure [3]. Such meager doses of organic fertilizers do not predetermine the growth of humus in the soil, its losses reach 0.2-0.6 $\mathrm{t} / \mathrm{ha}$, the humus balance is negative. Organic fertilizers are the most effective means of influencing the humus soil [2]. Of vegetable residues on humus substances only 20 - 30\% [7] turns from their total flow into the soil. The combined application of manure and plant residues improves the humus state and nutrient regime of the soil, its water-physical properties, structure and increases the yield of field crops [4, 10].

The impact of manure on the humus soil condition primarily depends on the doses $[1,6]$, the method and frequency of introduction and the type of soil $[1,10,12,13]$. An increase in the content of humus for manure is occurring on soils with a higher fertility [11]. Depending on the structure of crop rotation, 12-15 $\mathrm{t} /$ ha should be introduced on gray forest soils in Ukraine, and $8-9 \mathrm{t} /$ ha of litter manure in the black soil [10].

The purpose of the research is to study the effect of various doses of organic fertilizers on the long-term introduction of a gray forest soil in the chain of grain-growing crop rotation on the formation of the general and qualitative composition of humus.

Materials and methods of research. The study of agrochemical evaluation of various doses of organic fertilizers was carried out in a long field experiment of the Department of Agrochemistry of the National 
Academy of Sciences of the "Institute of Agriculture of the NAAN", which was laid in 1961. The soil of the experimental field is gray forest, large-leaved loamy, which was characterized by such indices before laying the experiment in 1961 at 0-20 -santi-meter layer of soil: humus (by Tyurin) $-1.45 \%$, total nitrogen (according to Kjeldal) - $0.071 \%$, mobile phosphorus (according to Chirikov) - $4.8 \mathrm{mg} / 100 \mathrm{~g}$ soil, exchangeable potassium (according to Maslova) $-4.6 \mathrm{mg} / 100 \mathrm{~g}$ of soil. The influence of systematic application of litter manure of 12 and $14 \mathrm{t} /$ ha over 45 years on the background of periodic liming (twice per rotation) was studied on changes in general and qualitative humus indicators at the end of IV - the beginning of the $\mathrm{V}$ rotation of the 10-grained crop rotation (a part of the crop rotation: clover on green fodder and winter wheat). In soil samples, carbon was determined by the method of B.A. Nikitina and V.Ya. Fishman [5]. Fractional group composition was determined according to VV methodology. Ponomareva and T.A. Plotnikova [9], optical density of humic acids - by the method of T.A. Plotnikova and VV Ponomareva [8].

Research results. The analysis of the results (Table 1) showed that without the use of fertilizers, the content of humus in the arable layer of soil decreased in relative values by $27.93 \%$, relative to the initial level $-1.45 \%$. In the underlying layer of soil, its content was $0.772 \%$, which is less than the arable layer by $26.12 \%$. Reduction of humus occurred due to mineralization processes, which prevailed over immobilization.

The application of $12 \mathrm{t} /$ ha of manure contributed to an increase in the content of humus in the arable soil layer to $1.424 \%$, which was $36.27 \%$ higher than the control, and its value was lower by $1.79 \%$ to the baseline. In the underlying layer of soil, the humus content was $1,005 \%$, which is more than control at $30,18 \%$. Such a dose of manure, though, improved the humus soil, but did not provide a deficit-free humus balance in the soil. Calculations of the balance of humus prove: to achieve a deficit-free humus balance, it is necessary to make not $12 \mathrm{t} /$ ha manure, and $13.9 \mathrm{t} /$ ha. For the introduction of $24 \mathrm{t} /$ ha of manure, the content of humus in the arable layer of soil increased to $1.623 \%$, which indicates the formation of a positive balance of humus, the content of which is more than $12 \mathrm{t} /$ ha of manure at $13.97 \%$. In the underlying soil layer, the humus content was $1.239 \%$, with an increase of $23.26 \%$ compared with option 6 , with $12 \mathrm{t} /$ ha of manure.

Analysis of the qualitative composition of humus (Table 2) in the non-fertilizer application shows that the quality of humus deteriorated due to a decrease in the content of humic acids and an increase in the content of fulvic acids (especially in the subsoil soil layer) due to the fractions: number 1 , which is free and bound with mobile half-oxides, number 2 , which is connected with calcium, and number 3 , which is connected with clay fraction and stable pentaholic acids.

The number of fulvic acids increased in the arable soil layer to $35.3 \%$, which is more than the amount of humic acids by $41.65 \%$, in the subsoil layer of the soil - by $38.93 \%$, which is more by $90.37 \%$ than the humic acids in this layer of soil. Because of such a distribution of acids, the ratio Сгк: Сфк in the arable soil layer is 0.70 , in the underlying - 0.52 . Type of humus formation - fulvato-hutumny.

For manure $12 \mathrm{t} /$ ha quality humus indicators have improved significantly. In the arable layer, the content of humic acids increased by $21.91 \%$, in the underworld - by $19.107 \%$ compared to the control. An increase in the number of humic acids occurred in the arable layer at the expense of faction number 1 - by $40,1 \%$ and number 3 - by $20,71 \%$, and in the underlying layer of soil at the expense of fraction number 1 by $104,78 \%$ and a small amount - fractions No. 2 and No. 3. There was a decrease in the number of fulvic acids in the arable soil layer compared with control at $36.83 \%$ due to all fractions and, in particular, aggressive fraction No. 1a. In the underlying layer, a decrease in the number of fulvic acids was observed as compared with control at $23.76 \%$ due to the same fractions as in the arable layer of soil. Such a change of humic and fulvic acids provided the ratio Сгк: Сфк in the arable layer of soil - 1,36, in the subterranean 0,82 . Humus type in the arable layer - human-fulvatny, in the subterranean - full-hut. Significantly increased the optical density of humic acids compared with control.

Manure application of $24 \mathrm{t} /$ ha contributed to a significant improvement in the formation of the qualitative composition of humus compared to $12 \mathrm{t} /$ ha manure. The amount of humic acids increased in the arable layer to $34.71 \%$, which is more by $14.25 \%$ to the manure dose of $12 \mathrm{t} /$ ha. The increase in humic acids occurred at the expense of all fractions and, in particular, fraction No. $1-20.85 \%$.

In the underlying soil layer, the content of humic acids also increased to $25.88 \%$, which is more by $6.24 \%$ compared to option 6 , due to all fractions. The content of fulvic acids in the arable layer decreased to $18.25 \%$, which is less than the manure dose of $12 \mathrm{t} /$ ha by $18.16 \%$, in the underlying soil layer the content of 
fulvic acids was $21.14 \%$, which is lower than in version 6 , at $28,77 \%$. These reductions occurred at the expense of all factions and, in particular, fractions No. 2 and No. 3. Due to the reduction of fulvic acids and the increase of humic acids, the correlation of Сгк: Сфкк in the arable layer expanded to 1.90, in the underlying - 1.22. The type of humus formation is human-fulvant. Significantly improved the optical density of humic acids up to 6.9 in arable and up to 4.4 in the underlying layer of soil.

\section{Conclusions}

According to the research found that without the use of fertilizers in cultivated grain crop rotation decreased humus content and deterioration of its quality indicators, particularly in the subsoil layer of soil. The use of 12 tons of manure per 1 ha of crop rotation area, humus content and its quality indicators improved in relation to control variant, but to achieve a balanced balance of humus impossible. To form, calculations show that non-deficit balance of humus should make $13.9 \mathrm{t} /$ ha of manure. Adding 24 tons of manure per 1 ha of crop rotation area provides a positive balance of humus and improving its quality indicators and subsoil in the arable soil layers. Build formation of humus humate-fulvic. Application of manure in intensive agriculture in doses exceeding the need of cultures in power humusovannosti improves soil quality indicators and improvement of humus.

\section{Bibliography}

1. Avdonyn N.S. Ahrokhymyya/N.S. Avdonyn. - M.: Yzd-vo MHU, 1982. - S. $318-337$.

2. Ehorov V.V. Nekotorыe voprosы povыshenyya plodorodyya pochv/V.V. Ehorov//Pochvovedenye. 1981. — № 10. — S. 71 - 79.

3. Kamins'kyy V.F. Rol' sivozmin u suchasnomu zemlerobstvi/V.F. Kamins'kyy, P.I. Boyko//Visn. ahrar. nauky. - 2013. - № 6. - S. $5-9$.

4. Kyzyakov V.E. Nakoplenye pytatel'nыkh veshchestvza schet pozhnyvnыkh y kornevыkh ostatkov zernovыkh kul'tur v obыknovennom chernozeme/V.E. Kyzyakov//Ahrokhymyya. 1981. — № 2. - S. $49-53$.

5. Nykytyn B.A. Ob usovershenstvovanyy metoda opredelenyya uhleroda v pochve//B.A. Nykytyn, V.Ya. Fyshman//Khymyya v sel. khoz-ve. — 1969. — № 3. - S. 76 - 77.

6. Pannykov V.D. Teoryya y praktyka povыshenyya plodorodyya pochv/V.D. Pannykov//Vestn. s.-kh. nauky. -1981 . - № 12. - S. $14-23$.

7. Pestryakov V.K. Okul'turyvanye pochv Severo-Zapada/V.K. Pestryakov. — L.: Kolos, 1977. — S. 227 232.

8. Plotnykova T.A. Uproshchennыy varyant opredelenyya optycheskoy plotnosty humynovыkh veshchestv s odnym svetofyl'trom/T.A. Plotnykova, V.V. Ponomareva//Pochvovedenye. — 1967. — № 7. — S. $73-85$.

9. Ponomareva V.V. Opredelenye hruppovoho y fraktsyonnoho sostava humusa po skheme Y.V. Tyuryna/V.V. Ponomareva, T.A. Plotnykova//Ahrokhymycheskye metodb yssledovanyya pochv: yzd-vo 5-e dop. y pererab. - M.: Nauka, 1975. - S. $47-55$.

10. Roychenko H.Y. Humusovыy fond y dynamyka orhanycheskoho veshchestva pakhotndkh pochv pravoberezhnoy Lesostepy USSR/H.Y. Roychenko, N.M. Hlushchuk//Pochvovedenye. — 1981. — № 3. S. $21-34$.

11. Sdobnykov S.S. Yspol'zovanye orhanycheskykh udobrenyy y ykh vlyyanye na plodorodye pochvы/S.S. Sdobnykov//Zemledelye. - 1982. - № 1. - S. 56 - 59.12. Algner H. Organische dungung faustzahlen/H. Algner. - 1980. - S. $207-227$.

13. Chesnin L. Mountain of Resources for soil improvement/L. Chesnin//Farm Ranch and Home Quarterly. - 1980. — v. 27, № 2. - P. $18-21$.

14. Gorlitz $H$. nahrstoffonds des organischen dunger/H. Gorlitz, H. Koriath//Feldwirtschaft. - 1981. Bol. 22. - H. 3, S. $119-120$.

15. Kofoed A. Dam Naturgodning og naeringsstot'balance/A. Kofoed//Ugeskrift for Jordburg. — 1979. arg. 124, № $1-2$. - S. $3-10,19$. 